\title{
BOORIN NIUKKUUS RAUDANPUUTOSTAUDIN AIHEUTTAJANA KAURASSA RAHKASUOLLA
}

\author{
Reijo Heinonen \\ Yliopiston maanviljelyskemian laitos, Helsinki
}

Saapunut 8. 11. 1961

Kiikalan pitäjässä sijaitsevan Jussilan talon uudisviljelyksellä esiintyi vv. 1958 - 61 kaurassa puutostauteja, jotka aiheuttivat alkuvuosina $1-2$ ha:n alueella lähes täyden kadon. Raivio on rahkarämeellä, jossa turpeen paksuus on $20-100 \mathrm{~cm}$. Varsinkin suon keskiosassa turve on löyhää ja heikosti maatunutta $\left(\mathrm{H}_{2}-3\right)$. Turpeen alla on karkeata hietaa, joka suon reuna-alueella ulottuu pintaan saakka. Kolmen vuoden aikana tehdyt kenttä- ja astiakokeet sekä maa- ja kasvianalyysit osoittivat, että alueella oli kalkin ja pääravinteiden lisäksi samanaikaisesti puutetta useista hivenaineista. ${ }^{1}$

\section{Kuparin puute}

Ensimmäiseksi raivatulla suon ohutturpeisella reuna-alueella ilmeni kaurassa heti voimakas kuparin puutteesta johtuva keltakärkitauti. Kasvusto kellastui ja kuihtui keskikesällä, versoi sitten uudelleen, mutta ei tehnyt lainkaan jyvää. Olkinäytteen kuparipitoisuus oli äärimmäisen pieni, alle 1 ppm. Kuparilannoituksen jälkeen alue on kasvanut hyvin ja raivausta jatkettaessa turvemaalle annettiin heti aluksi kuparisulfaattia $50 \mathrm{~kg} / \mathrm{ha}$. Sittemmin on kasveissa ilmennyt vain joitakin hajanaisia merkkejä kuparin puutteesta.

\section{Raudan puute}

Kuparilannoituksesta, kalkituksesta ja täyslannoituksesta huolimatta suon paksuturpeisella osalla esiintyi kaurassa voimakasta kellastumista, joka pahimmillaan ehkäisi kasvun kokonaan. Kloroosi vastasi nyt tarkalleen LundBLAdin (1, s. 97 ja kuva 2) ja Wallacen (9, kuvat 24,25 ja 29) selostusta ja värivalokuvia

1 Kirjoittaja lausuu parhaat kiitoksensa maanviljelijä Yrjö Vuoristolle, joka antoi virikkeen tähän tutkimukseen ja on myötävaikuttanut siihen monin tavoin. 
raudan puutetta kärsivästä kaurasta: pari vanhinta lehteä vihreitä, nuoremmat keltajuovaisia, mutta eheitä ja eläviä kärkeen saakka. Tosin kasvustosta saattoi löytää myös joitakin kuolleita rihmaksi kiertyneitä lehtikärkiä, jotka viittaisivat kuparin puutteeseen, mutta näitä esiintyi sekä vihreän että kloroottisen kasvuston joukossa ja ne johtuvat kenties kuparin epätasaisesta leviämisestä.

Vahvasti happaman rahkasuon kalkitsemattomassa osassa kloroosi voisi johtua myös kalsiumin puuttesta, joka LundBLADin mukaan (1, s. 30 ja kuva 29) aiheuttaa melkein samanlaisia symptoomeja kuin raudan puute. Kun kloroosia esiintyi kuitenkin myös kalkitulla alueella, kalkin puute ei voi olla ainakaan pääasiallinen syy.

Diagnoosin varmistamiseksi suoritettiin 23.6. 60 pienillä koealoilla ruiskutuksia rautasulfaattiliuoksella ja tehtiin muutamia kasvianalyysejä. Ruiskutus aiheutti parin viikon kuluessa selvää vihertymistä, joka kuitenkin meni ohi, eikä pelastanut kasvustoa.

Taulukko 1. Kauran maanpäällisten osien kuiva-aineen koostumus rahkasuon uudisviljelyksellä Kiikalassa.

Table 1. Composition of the above-ground parts of oats, dry matter basis. Newly reclaimed sphagnum peat, Kiikala, SW Finland.

\begin{tabular}{|c|c|c|c|c|}
\hline & $\begin{array}{r}23 . \\
\text { Terve } \\
\text { Healthy }\end{array}$ & $\begin{array}{l}1960 \\
\text { Sairas } \\
\text { Chlorotic }\end{array}$ & $\begin{array}{l}\quad 9.8 . \\
\text { Terve } \\
\text { Healthy }\end{array}$ & $\begin{array}{l}1960 \\
\text { Sairas } \\
\text { Chlorotic }\end{array}$ \\
\hline N \% & . & . & 1.78 & 2.52 \\
\hline Tuhka $-A s h \%$ & 6.85 & 6.15 & 7.21 & 5.61 \\
\hline $\begin{array}{l}\text { Fe ppm } \\
\quad \text { Normaali }- \text { Normal }^{1}\end{array}$ & $\begin{array}{r}97 \\
100\end{array}$ & 57 & 86 & 23 \\
\hline $\begin{array}{l}\text { Cu ppm } \\
\quad \text { Normaali }- \text { Normal }^{2}\end{array}$ & . & & & 6.5 \\
\hline \multicolumn{5}{|l|}{$\begin{array}{l}\text { Nicholas, ks. 9, p. } 34 . \\
\text { ref. } 2,6 .\end{array}$} \\
\hline \multicolumn{5}{|c|}{$\begin{array}{l}\text { Kasvianalyysejä varten otettiin kahdesti näyte kloroottisesta kasvustosta ja } \\
\text { terve vertailunäyte mahdollisimman läheltä sitä. } 23.6 .60 \text { näytteet otettiin klo- } \\
\text { roottiselta saralta, jossa oli tervettä kasvustoa laikuittain, varsinkin hietaa saaneilla } \\
\text { ojanvarsilla. 9. } 8 \text {. } 60 \text { otettu näytepari on terveeltä saralta, jossa vain sattumalta } \\
\text { lannoittamatta jäänyt kaista oli kloroottinen. Taulukosta } 1 \text { ilmenee, että terveiden } \\
\text { kasvien rautapitoisuus on ollut lähellä normaalia, mutta kloroottisten vain noin } \\
\text { puolet tai neljännes siitä. Kuparipitoisuus oli molemmissa normaali. Typpipitoisuus } \\
\text { oli kloroottisissa kasveissa suurempi, mutta tuhkapitoisuus pienempi kuin terveissä. } \\
\text { SorTEBERG (8) on todennut raudan puutteesta kärsivässä rahkasuon timoteissa } \\
28 \text {-90 ppm:n rautapitoisuuksia, siis samaa luokkaa kuin taulukossa } 1 \text { esitetyt. } \\
\text { Edellä esitetyn perusteella näyttää ilmeiseltä, että kloroosin välittömänä syynä } \\
\text { oli raudan puute. Seuraavassa luvussa selostetut havainnot osoittavat kuitenkin, } \\
\text { että primäärisenä syynä oli boorin puute. }\end{array}$} \\
\hline
\end{tabular}




\section{Boorin puute}

Käytettävissä olevien tietojen perusteella voidaan boorin puutetta kaurassa pitää hyvin harvinaisena. Onhan viljakasvien boorin tarve yleensäkin vähäinen ja kauralla se on ilmeisesti kaikkein pienin $(3,10)$. Tässä yhteydessä huomio kiintyi booriin, kun täysin korjautuneella saralla sattumalta ilman booripitoista lannoiteseosta jäänyt kaista oli voimakkaasti kloroottinen. Käytetyn NPK-lannoiteseoksen sisältämä laskettu rautamäärä oli niin vähäinen, että kloroosin häviämisen pääteltiin johtuvan välillisesti jostakin muusta tekijästä kuin raudasta.

Kloroottisten kasvien juuret olivat hyvin heikosti kehittyneitä ja ulkonäöltäänkin epänormaaleja. Niissä oli tiheässä lyhyitä paksuja haaroja ja kyhmyjä ja niiden väri oli kellanruskea, mikä erotti ne myös värivalokuvissa selvästi terveiden kasvien valkeista juurista. Vastaavat erot ilmenivät myös seuraavana kesänä järjestetyissä kenttä- ja astiakokeissa, jotka osoittivat, että juuriston epänormaalisuus varmuudella johtui boorin puutteesta. Näiden kokeiden yksityiskohtaisempi selostaminen ei kuitenkaan ole enää ajankohtainen, sillä KoroNowsKı $(3,4)$ on vast'ikään julkaissut laajahkon laboratorio-olosuhteissa suoritetun tutkimuksen boorin puutteen vaikutuksesta viljakasveihin, ja hänen juuria koskevat havaintonsa ovat täysin samanlaiset kuin omamme. Erikoisen tyypillinen on valokuva boorin puutetta kärsivän kauran juuresta (3, s. 36). (Boorin merkitys kaksisirkkaisten kasvien juuriston kehitykselle tunnettiin jo 30-luvulla, mutta KoRONOWSKI lienee ensimmäinen, joka on kuvannut absoluuttisen puutteen aiheuttamia juuristosymptoomeja rukiissa, vehnässä, ohrassa ja kaurassa).

23. 6. 60 otettiin taulukon 1 kasvinäytteitä vastaava maanäytepari, josta saadut analyysitulokset (taulukko 2) viittaavat sekä boorin että raudan puutteeseen.

Taulukko 2. Analyysituloksia puutostautialueen maasta. Rauta ja kupari määritetty liuottamalla tuhka 2-n suolahappoon; vesiliukoinen boori.

Table 2. Soil analyses from the deficiency area, Kiikala, SW Finland. Exchangeable calcium given as $\mathrm{CaCO}_{3}$; iron and copper determined from ash dissolved in $2 \mathrm{~N} \mathrm{HCl}$; water soluble boron:

$\begin{array}{cc}\begin{array}{c}\text { Hyväkasvuinen, } \\ \text { hiekoitettu } \\ \text { kohta }\end{array} & \begin{array}{c}\text { Huonokasvuinen } \\ \text { rahkaturve }\end{array} \\ \text { Productive, } & \text { Deficient } \\ \text { sanded area } & \text { sphagnum peat }\end{array}$

Hehkutushäviö \% - Loss on ignition \%

23

$\mathrm{CaCO}_{3} \mathrm{tn} / \mathrm{ha} / 20 \mathrm{~cm}$

$\mathrm{Cu} \mathrm{kg/ha/20}$

Tyydyttävä - Satisfactory ${ }^{1}$

$\mathrm{Fe} \%$

B ppm

Tyydyttävä - Satisfactory ${ }^{1}$
3.0

50

$\begin{array}{lcc} & 15-25 & \\ 0.24 & & 0.04 \\ 2.0 & & 0.1 \\ & 0.7-1.8 & \end{array}$

1 Standards used by the soil testing service (5) 
Varsinkin boorin määrä on turpeen alhaisen tilavuuspainon huomioonottaen erittäin pieni kloroottisella alueella. Muilta osin maa-analyysit antoivat rahkaturpeille tyypillisiä arvoja; kuparipitoisuus on asianomaisen lannoituksen ansiosta riittävä.

Kasvianalyyseissä (taulukko 1) ilmennyt kloroottisen kasvuston suurempi typpipitoisuus ja pienempi tuhkapitoisuus ovat myös sellaisia ilmiöitä, joiden on todettu liittyvän boorin puutteeseen (ks. 7, s. 156-157).

Kaiken kaikkiaan näyttää varmalta, että Kiikalassa todettu raudanpuutoskloroosi oli boorin puutteen seurausilmiö. Vaikka turpeen rautapitoisuus on alhainen, se voi tyydyttää kasvien tarpeen, jos riittävä boorin saanti yhdessä kalkituksen ja täyslannoituksen kanssa turvaa juuriston normaalin kehityksen.

\section{Tarkastelua}

Norjassa on eräällä rahkasuolla todettu liiallisen kalkituksen aiheuttavan boorin puutetta monissa kasveissa, mm. viljoissa $(10,11)$. Turpeen alkuperäinen $\mathrm{pH}$ oli 3.6 ja kohtuullinen kalkitus, joka nosti $\mathrm{pH}:$ n 5.5:een, ei vielä haitannut viljakasveja, mutta $\mathrm{pH}$ 6.5:ssä häiriöt olivat jo tuntuvat. Taudinkuva oli kuitenkin tällöin osittain toinen kuin Kiikalassa ilmenneessä absoluuttisessa puutteessa. Ylikalkitus aiheutti poikkeuksellisen runsaan versonnan, pituuskasvun ja tähkänmuodostuksen häiriintymisen ja heikon jyväsadon. Kummassakin tapauksessa todettiin juurten epänormaali haaroittuminen, mutta ylikalkituksen aiheuttamassa boorin puutteessa juuristomassa kokonaisuudessaan ei vähentynyt, vaan päinvastoin lisääntyi (10).

Monissa maissa on todettu raudan puutetta rahkasoilla (1, s. 59, 8), mutta sen kytkeytymistä boorin puutteeseen ja boorin ratkaisevaa vaikutusta kauran juurien kehitykseen ei liene aikaisemmin havaittu kenttäolosuhteissa. Rahkasoiden viljelyynoton laajentuessa on kuitenkin syytä varautua siihen, että esiintyy rautakloroositapauksia, jotka voivat liittyä monimutkaisella tavalla muihin kasvinravitsemuskysymyksiin. Esim. kuparilannoituksen on havaittu lisäävän kloroosia (8). Se seuraa tällöin sitä kasvifysiologiassa yleistä ilmiötä, että jonkin aineen puute ilmenee räikeämpänä, kun toiset tekijät saatetaan suotuisammiksi.

Kalkin vaikutus kasvien raudan saantiin on hyvin monisuuntainen. Sellaisenaan se vähentää raudan liukoisuutta, mutta se vähentää myös fosforin liukoisuutta turvemaassa ja estää täten vesiliukoista fosfaattia saostamasta rautaa kasveille kelpaamattomaan muotoon (8). Juuriston kehitystä edistäessään kalkitus voi boorin tavoin parantaa raudansaantimahdollisuuksia. Kaiken kaikkiaan kohtuullisen kalkituksen myönteiset vaikutukset lienevät rahkasuolla suuremmat kuin kielteiset, sillä sen on havaittu vähentävän raudanpuutoskloroosia. Monipuolisimmin vaikuttava yleislääke löyhällä turvemaalla esiintyviin fysiologisiin häiriöihin oli kuitenkin norjalaisissakin kokeissa kivennäismaan käyttö maanparannusaineena (8).

\section{Yhteenveto}

Vasta raivatulla rahkarämeellä Kiikalassa todettiin kaurassa ensiksi kuparin puute (keltakärkitauti) ja sen tultua korjatuksi voimakas raudanpuutoskloroosi, 
jota kuitenkaan ei ollut hietaa saaneilla ojanvarsilla. Kloroosin perussyyksi todettiin boorin puute, joka ehkäisi juuriston kehityksen. Mitään kasvuhäiriöitä ei esiintynyt alueilla, jotka olivat saaneet kalkituksen ja NPK-lannoituksen lisäksi kuparia ja booria.

\section{K I R J A L L I S U U T T A}

(1) Bristsjukdomar, $144 \mathrm{~s} .+32$ värikuvaa. Växtnäringsnytt, Stockholm 1959.

(2) Karlsson, N. 1951. Något om biogena mikroelement och deras förekomst i marken och fodret. Växtnäringsnytt 7,5: 24-31.

(3) Koronowski, P. 1961 a. Morfologische Veränderungen an Mais und anderen Getreidearten bei Bormangel. Z. Pfl. Ernähr. Düng. Bodenk. 94: 25-39.

(4) - 1961 b. Anatomische Veränderungen an Mais und anderen Getreidearten bei Bormangel. Ibid 94: 53-67.

(5) KURKI, M. 1957. Viljavuustutkimuksen hyväksikäyttö, 16 s. Viljavuuspalvelu Oy, Helsinki.

(6) LundBlad, K. 1951. Olika lantbruks- och köksväxters förbrukning av växtnäringsämnen. Växtnäringsnytt $7,5: 32-43$.

(7) Scheffer, F. \& Welte, E. 1955. Lehrbuch der Agrikulturchemie und Bodenkunde. II Teil. Pflanzenernährung. $240 \mathrm{~s}$. Stuttgart.

(8) Sorteberg, A. 1961. Kar- og markforsøk med kopper og jern. Summary: Pot and field experiments with copper and iron. Res. Norw. Agr. 12: 81-140.

(9) Wallace, T. 1951. The diagnosis of mineral deficiencies in plants by visual symptoms. $107 \mathrm{~s} .+312$ värikuvaa. London.

(10) ØDELIEN, M. 1938. Virkning av bormangel og bortilsetning på forskjellige vekster dyrket i hvitmosetorv med større og mindre kalkinnhold. Summary: Effects of boron deficiency and boron application on certain crop plants grown in Sphagnum peat with varying calcium content. Meld. Norges Landbr.høisk. 17: 54-89.

(11) - - 1942. Fortsatte forsøk med bor. Zusammenfassung: Fortgesetzte Versuche mit Bor. Ibid 22: $487-534$.

\section{S U M M A R Y :}

BORON DEFICIENCY AS A CAUSE OF IRON CHLOROSIS IN OATS ON A SPHAGNUM PEAT

Reijo Heinonen

Department of Agricultural Chemistry, University of Helsinki

A series of minor element deficiencies was observed in oats on a newly reclaimed sphagnum peat in Kiikala, SW Finland. Firstly, a copper deficiency caused a complete failure of the crop and an analysis revealed a copper content of less than 1 pmm in the unsound straw. After an application of copper sulphate $(50 \mathrm{~kg} / \mathrm{ha})$, a severe iron chlorosis appeared, which damaged the crop except on ditch-sides where sand had been spread. Analyses of chlorotic and healthy plants and corresponding soil samples are given in Tables $\mathbf{1}$ and $\mathbf{2}$.

The principal problem was, however, a boron deficiency, which prevented normal development of roots. The roots of the chlorotic plants were weak, brownish, with many short and thickened branches (symptoms identical with those recently described by Koronowski). An application of boron (in connection with lime, NPK and $\mathrm{Cu}$ ) made possible a normal root development which in turn enabled the plants to make use of the scanty supply of iron in a greater volume of soil, and to produce a good crop yield. 